\title{
Astronomy, Latinity, Enlightenment: Niels Krog Bredal's Poems Commemorating the Transits of Venus, 1761 and $1769^{1}$
}

\author{
Author \\ Per Pippin Aspaas \\ University Library, University of Troms $\varnothing$ - The Arctic University of Norway \\ NO-9037 TROMS $\varnothing$, Norway
}

\section{Abstract}

The subject of this article is three pieces of elegiac Latin poetry, written in Trondheim by the mayor of the town, Niels Krog Bredal. The occasion for the poems were the transits of Venus occurring in the years 1761 and 1769, a rare phenomenon attracting considerable attention from natural philosophers of the Enlightenment and spurring numerous scientific expeditions across the globe. Bredal wrote the poems to commemorate expeditions undertaken by Thomas Bugge and Urban Bruun Aaskow (Trondheim, 1761), Christian Gottlieb Kratzenstein (Trondheim, 1769), and Maximilianus Hell (Vardø, 1769). Bredal is primarily remembered as an important, albeit controversial, figure within Dano-Norwegian theatre history. His Latin poems reveal another side of his character, a person with a keen interest in the natural sciences, and more than willing to express his insights through poetry. The article includes an edition with critical apparatus, translation, and commentary.

\section{Keywords}

Niels Krog Bredal; occasional poetry; transits of Venus; eighteenth century; use of Latin

\footnotetext{
${ }^{1}$ This is the final, accepted manuscript version (after peer review, editorial work and proof reading) of the article published in Symbolae Osloenses 90 (2016), 205-234, DOI: http://dx.doi.org/10.1080/00397679.2016.1235875. The publisher Taylor \& Francis does not allow the published PDF to be made available Open Access without paying a heavy fee. However, the difference between this version and the publisher's PDF should consist of pagination and lay-out only.

$$
\text { - The author }
$$
}




\section{The poet}

Niels (or Nicolaus) Krog Bredal was born on 6 September $1733^{1}$ in Trondheim, at that time the northernmost town in the Kingdom of Denmark and Norway. The son of a judge (Lagmand, i.e. lawspeaker) and a descendant of bishops on both his mother's and his father's side, he received schooling at Trondheim Cathedral School until 1747. He then matriculated at Copenhagen University, where he studied Law. During the 1750s, especially after he graduated from the university in December 1755, he produced various literary works, including plays for the stage. Bredal stayed in the capital until the spring of 1761, when he returned to his hometown to take on the office as mayor (Borgermester), a capacity in which he served until the summer of 1770 . He then moved back to Copenhagen, where he soon became director of "Den danske Skueplads", the most important theatrical stage in the capital. He died in Copenhagen on 26 January 1778, unmarried. ${ }^{2}$

Bredal is primarily remembered as a playwright and a theatre director of mixed reputation. His favoured genre was the "Synge-Spil" (in German: sg. Singspiel, pl. Singspiele), a kind of opera in which singing alternates with recitative, usually with a plot set in a pastoral environment. Bredal is credited as an innovator with his introduction of this genre into DanoNorwegian literature (e.g. Bull 1916, 124-141; Krogh 1924, 10-17; Aarset 1999). His first in a series of Danish Singspiele was Gram og Signe, eller Kierligheds og Tapperheds Mesterstykker [Gram and Signe, or Heroic Acts of Love and Bravery] (1756), for which he had found inspiration in the Gesta Danorum of Saxo Grammaticus, in order - as he himself stated in the preface - "to be Danish even in this respect as well". ${ }^{3}$ Further plays by Bredal were in the latter half of the 1750s performed at "Den danske Skueplads", where the comedies of the late Ludvig Holberg had been staged and where Bredal was later to become director. After his nine years in Trondheim, Bredal's comeback on the Copenhagen scene saw a flying start with the Singspiel Tronfølgen i Sidon [The Royal Succession in Sidon] from 1771. After a few months, however, Peder Rosenstand-Goiske, a young student and literary critic published a devastating review of the play in the first issue of his periodical, Den dramatiske Journal. Bredal answered in the form of a one-act "postludium", which he called Den dramatiske Journal, eller Critik over Tronfølgen i Sidon [The Dramatic Journal, or Critique of 'The Royal Succession in Sidon']. The performance of the postlude caused scandalous skirmishes between military officials who sided with Bredal and partisans of RosenstandGoiske (e.g. Carlson 1975; Gaasland 1999). After this, Bredal retreated to a more secluded role. Although he did promote young colleagues, particularly as a central figure within an informal circle of Copenhagen-based Norwegian authors known as "Det norske Selskab" (Bliksrud 1999b), his own artistic contributions henceforth mainly consisted of translations of plays by contemporary French playwrights such as Charles-Simon Favart and Jean-François Marmontel. $^{4}$

For generations, Danish and Norwegian historians of literature have been rather lukewarm towards Bredal's achievements as a writer. It is only recently that he has gained some recognition as an able dramatist and an important inspirer for many of his contemporaries. "With regard to the eighteenth-century Norwegian-Danish world of drama there was hardly any single person who had such a prominent position during his lifespan as Niels Krog 
Bredal, but has yet been so utterly forgotten by posterity," Norwegian professor of comparative literature Hans Erik Aarset writes. ${ }^{5}$ Professor of Nordic literature Liv Bliksrud emphasizes that his Singspiele were really the lyrics of music (libretti); they should not be judged as dramas meant for reading $(2010,244)$. Moreover, Bredal not only contributed the lyrics to numerous Singspiele, he also composed musical scores of his own, including a special cantata for Copenhagen University in 1777. The instant success of his debut Gram og Signe (1756) is said to have rested partly with his piecing together of elements from several operas (by Giuseppe Sarti) into a coherent whole to match the lyrics. Bredal's interest in music also took on a theoretical form, as seen in his preface to a hugely influential textbook by Niels Hansen, published in 1777 (cf. Høgel 1980).

Bredal was productive outside the performing arts as well. His long list of publications includes a Danish poem on the benefits of science to society at large (1768); a Danish translation of a German work on smallpox inoculation (1762; cf. Eriksen 2010); under a false name, a Danish epistolary fable in the tradition of Holberg's Nicolai Klimii iter subterraneum (1767), and so forth. His literary debut was in fact a verse translation of parts of Ovid's Metamorphoses with commentary and introduction in Danish (Book I, 1752; Books I-V, 1758). ${ }^{6}$ These parts of his production, however, have received far less attention in the scholarly literature than his dramas. His Latin poetry has to the best of my knowledge not been studied at all. ${ }^{7}$

Unfortunately, most of Bredal's Latin poems were never printed. These are either lost or are still awaiting discovery. In terms of printed works, his debut in the Latin language came already in March 1753, when the "Oneiro-Kosmos", or ONEIPO-KO $M O \Sigma$. Id est Mundus in Somnio, Poëma Philosophico-Heroicum [The Dreamworld, a Philosophical-Heroic Poem] appeared in the Copenhagen weekly, Nye Tidender om Larde og Curieuse Sager (Bredal 1753). In a mixture of dactylic hexameters and prose, the 19-year old Bredal tells about a world that he has "visited" during his sleep, or rather, in a state of ecstasis when he was neither asleep nor awake. The hero of the ecstasis finds himself in a world whose inhabitants speak an unintelligible language. They live in forests, growing crops near a volcano that constantly threatens to extinguish their civilization, we are told in the first 105 hexameters. In a following prose section, Bredal presents his interpretation of the dream. The inhabitants of this dreamworld, he surmises, were really insects (lice or similar) living on the body of a man. The so-called volcano represented the man's breath; "earthquakes" were caused by the man's cough, etc. The text concludes with another set of verses (14 hexameters), in which the poet argues that not only human beings feel the pain of existence; it is simply as a result of the limits of the human intellect that certain philosophers fail to realize that humans are not the only living beings to have souls. Bredal's Oneiro-Kosmos is a good example of the "conte philosophique", in which contemporaries such as Voltaire, Diderot, and Holberg excelled. New discoveries in the natural sciences are baked into the narrative, whose implicit maxim in effect serves to undermine Christian creeds such as the alleged superiority of humankind over all other living beings (see further Aspaas, forthcoming).

Shortly after Bredal's arrival in Trondheim in 1761, Bishop Johan Ernst Gunnerus recruited him as secretary of the newly founded Norwegian Society for Sciences and Letters (With 
Andersen et al. 2009; Nøtvik Jakobsen 2015). In this capacity, Bredal is known to have routinely read aloud manuscripts that had been submitted to the Society's Transactions (Skrifter), kept records of the Society's meetings, and taken care of parts of its correspondence. However, his impact in this potentially quite influential position has received scant interest when compared to the three "founding fathers", namely, the historians Gerhard Schøning and Peter Friderich Suhm, and above all the polyhistor Gunnerus. Nevertheless, it is against the backdrop of Bredal's role as town mayor and secretary of a scientific society eager to gain recognition as a Dano-Norwegian centre of learning, that his poems commemorating the transits of Venus ought to be interpreted. First, however, some words on the astronomical phenomenon itself may be appropriate.

\section{The transits of Venus}

On two occasions during the eighteenth century, the planet Venus passed in front of the Sun as seen from Earth. The phenomenon had been witnessed only once before, by two amateur astronomers in the English countryside in 1639. This time around, the astronomical community was both larger and far better prepared. As secretary of the Royal Society of London, Edmond Halley had already in 1716 argued that skilled observers should station themselves in different parts of the globe to observe the next transits of Venus. These events had been calculated to take place on 6 June, 1761 (in the early morning hours as seen from Europe) and $3^{\text {rd }}-4^{\text {th }}$ June 1769 (around European midnight) (Halley 1717). If seen from different angles, Venus' path across the disc of the Sun would reveal tiny shifts, based on which the exact distances between the Sun, Earth, and Venus - and indeed the entire scale of the solar system - could be deduced. Halley's idea had a huge impact on natural philosophers of the Enlightenment. Determining the size of the solar system by means of the transits of Venus became a grand, collaborative enterprise capable of uniting astronomers in all major countries of Europe even in the midst of the Seven Years War, which lasted from 1756 to 1763 (e.g. Woolf 1959; Marlot 2004; Wulf 2012).

Observations of the 1761 transit were reported by at least 130 individual observers and attempted by many more, whose efforts were ruled out due to bad weather. In addition, there came some unforeseen optical problems, which complicated the exact recording of the phenomenon. As a result, it was decreed that in 1769 - the last possibility to witness a transit of Venus before 1874 - astronomers should spread themselves even further apart. In the final event, despite the fact that the 1769 transit was impossible to observe from large parts of Europe because it took place during the night, worldwide at least 154 individual observations were made (Aspaas 2012, 269-277). Two of the most important data sets from 1769 were provided by Captain James Cook and his team of observers in Tahiti (during midday), and by the Danish-sponsored group led by the Jesuit Maximilianus Hell, stationed at Vardø on the extreme north-eastern periphery of Norway (at midnight).

The global network of Venus transit observers was not only a scientific enterprise. It also entailed a quest for cultural recognition, in the sense that various countries competed for glory as "nations of science". In this century of Enlightenment, the ability to provide key data that could help solve one of the great riddles of the universe was no minor issue (e.g. Widmalm 
2013; Aspaas 2013). Scientific achievements were in turn represented in art and literature, as exemplified by the poems below.

\section{The recipients}

In 1761, Denmark-Norway planned to procure observations at several stations, the northernmost being Trondheim (Aspaas 2011; Voje Johansen 2011). The initiative for an expedition to Trondheim is said to have been taken by Christian Gottlieb Kratzenstein (17231795). Kratzenstein was born in Germany and educated at Halle University. He held a professorship at Saint Petersburg's scientific academy from 1748 to 1753, when he was recruited to Copenhagen as a professor of medicine and experimental physics, an office he held for the rest of his life. A true polymath, Kratzenstein corresponded with prominent representatives of the natural sciences all over Europe (Snorrason 1974; Splinter 2007). As we shall see, he went to Trondheim to observe the transit of 1769. In 1761, however, he stayed in Copenhagen, content to dispatch two students to the northernmost town of the Kingdom. These students were Thomas Bugge and Urban Bruun Aaskow.

The Dane Thomas Bugge (1740-1815) held a degree in theology from 1759, but worked as an assistant at Copenhagen's famous Round Tower Observatory (the Turris rotunda, or Runde Tårn) in the run-up to the transit of 1761. Clearly a rising star of Danish astronomy - he was soon after his return from Trondheim entrusted with the task of surveying large parts of Denmark, and, years later, appointed Astronomer Royal and director of Runde Tårn - Bugge was sent on this prestigious mission as a 20 year old (Aspaas 2012, 289-290). Along with him on the expedition, he had the even younger Danish student, later medical doctor, Urban Bruun Aaskow (1742-1806). After the expedition, however, Aaskow seems not to have pursued his interest in astronomy any further (Petersen 1887). Not much is known about their expedition except for a short notice by French astronomer Jérôme de Lalande in the Mémoires section of the proceedings of the Académie des Sciences of Paris (1763). According to Lalande, Bugge and Aaskow left Copenhagen on 5 May and reached Trondheim on 30 May. Here, they mounted their instruments in anticipation of the sunrise of 6 June 1761. The weather was not the best, and they only managed to record the very last part of the transit.

The Danish 1761 transit of Venus project was not successful. Not only had Bugge and Aaskow struggled with bad weather; also, at Runde Tårn, the serving director and Astronomer Royal Christian Horrebow failed to deliver reliable data, despite clear skies during the observation. The need to make amends in 1769 was probably even more acutely felt in Copenhagen when it emerged that its Nordic rival, Sweden, not only had delivered many high quality observations in 1761, but was also preparing to conduct an impressive programme in 1769. In this situation, the Counsel of the Realm decided to recruit an astronomer of international renown to make observations from far-northern Vardøhus (now Vard $\varnothing$ ). Here, the Midnight Sun would facilitate perfect conditions, good weather provided. The Jesuit Maximilianus (Maximilian) Hell (1720-1792), Imperial and Royal Astronomer of Vienna, accepted an invitation to go to Vardø. Although a Jesuit, Father Hell was clearly an ideal candidate. He had successfully coordinated such partial observations of the 1761 transit as were possible to make from Central Europe; he had published several works on the planet 
Venus and its transits; and since 1756 he edited the high quality Ephemerides Astronomicae ad Meridianum Vindobonensem, a large-format, annual almanac that included scientific reports and treatises in the form of appendices (Kontler 2014).

A travel diary by Maximilianus Hell's assistant Joannes (János) Sajnovics records how the expedition team travelled through Copenhagen in June 1768 before proceeding northwards to spend three weeks in Trondheim in August 1768. They here met with Bredal and other prominent members of the Trondheim Society of Sciences on several occasions. The expedition then travelled north in the company of Ernst Hagerup, county prefect (Amtmann) of Finnmark. Hagerup, however, left the expedition ship well before Vardø to reside in Alta. Hell and Sajnovics spent the winter 1768/69 in Vardø, observing the Northern Lights, examining the Sami language, recording the variations of the magnetic needle, researching the nightly luminescence of the sea known as "morild", etc. Hell planned to present all his observations - and the travel diary itself - in a richly illustrated, three-volume work in folio, the Expeditio litteraria ad Polum arcticum [Scientific Expedition by the North Pole] (Aspaas 2012, 361-381). Although this work was never accomplished, Hell triumphed by observing all vital parts of the transit in perfect weather conditions on the night between 3 and 4 June 1769. He then paid another visit to Trondheim from August 30 to September 12, 1769 on his way south to Copenhagen, where he was to present the core results of his expedition to the King - and to the wider world of learning. Hell's Venus transit observation from Vardø was immediately treated as doubtful by some influential astronomers abroad, resulting in a heated scientific controversy between Hell and adversaries in France, Sweden, and Russia (Aspaas 2010). At the time when Bredal wrote his poem of praise, however, nobody knew anything about the troubles ahead.

During the two Jesuits' stay in Trondheim, Sajnovics notes in his diary no small amount of festivity in their honour. Shortly upon their arrival, he records how Bredal presented some Latin verses to Hell (Sajnovics MS, 31 August, 1769): "hodie Consul Versus latinos obtulit $\mathrm{R}$ [everendissimo] P[atri] Hell". After this sentence, he fills in the mayor's name, "D[ominus] Bredahl", and adds the following lines:

Vult mundus decipi, decipiatur ergo! heist: Grosse herren wollen bedient seyn!

Nulla dies sine linea, heist: kein Tag ohne streich!

herr von Westen, komt von Norden, geht nach Süden, wird recomendiert von Osten.

The limerick-like irony is characteristic of Bredal's style. "Streich", the alleged equivalent of linea, bears the double meaning of a stroke of the pen as well as a joke. "Von Westen" alludes to Thomas von Westen, the missionary renowned for having christened the souls of the Sami in northernmost Norway. "Von Osten" is Johan Wibe von der Osten, commander of the military of the northern parts of Norway and general at Kristiansten Fortress in Trondheim. His garrison had numerous mercenary soldiers from catholic countries. During their two visits in Trondheim, Hell and Sajnovics celebrated mass for these soldiers virtually every day, upon encouragement from von der Osten (cf. Kragemo 1960; Holtzapfel 1979; Sogner 2003). The humour of the punchline probably satires religious scepticism: had Hell's expedition really 
been a "purely scientific" undertaking, or was the Jesuit visitor in fact engaged in a clandestine religious mission under military tutelage?

It is slightly puzzling that Sajnovics records this on 31 August, whereas Bredal's own manuscript for the Latin poem, edited below, is dated 1 September 1769. Perhaps one of the two dates is incorrect. In any case, even more poetry - probably in Latin - by Bredal is known to have been presented to Hell and Sajnovics during their expedition, but except for the poem below those verses have not been found. ${ }^{9}$

As for Professor Kratzenstein, he clearly intended to stay in Copenhagen also for the transit of 1769. However, any astronomer could immediately see that to have just one expedition stationed in the far north would be risky. What if the skies of Vardø turned out to be completely overcast? Denmark-Norway would then be left with nothing, whereas Sweden, which in fact planned three stations in the far north, was likely to strengthen its scientific prestige even further, at the expense of Danish science. During Hell's visit in Copenhagen a year ahead of the transit, Kratzenstein therefore decided to embark on a "private" expedition to Trondheim. ${ }^{10}$ Kratzenstein travelled north in the spring of 1769 , by ship, to Trondheim, where he arrived on 29 May (Voje Johansen 2011). The transit was to begin around 9 pm on $3^{\text {rd }}$ June and end around 3 am the next morning. Although the Sun would drop below the horizon during the night (Trondheim is several miles south of the Arctic Circle), nevertheless, thanks to the short summer night the crucial stages at beginning and end would in theory be observable, if only the sky was serene. Kratzenstein had no such luck. First, he experienced a shipwreck on his way north, "Cel[eberrimus] D[ominus] Kratzenstein in itinere maritimo Hafnia Drontheimium tendens terribile Naufragium passus, vitam, enatando ad littora, salvare coactus est" [The celebrated Mr. Kratzenstein experienced a terrible shipwreck during his sea voyage from Copenhagen to Trondheim and had to swim ashore in order to save his life] (Hell 1790, 360). Then, he saw nothing but rainclouds for the entire duration of the transit, "la pluie m'ôta la vue du passage", as Kratzenstein explained in a letter to his colleague Lesage

(Prevost 1805, 400). Kratzenstein set course back to Copenhagen shortly after Venus had passed over the disk of the Sun, completely hidden behind clouds, not to return "ultra viginti lustra", or more precisely, in 1874.

\section{The poems}

The three poems are presented in chronological order. Readers who are not fluent in Latin are advised to consult the translations that follow immediately after each original.

\section{1: For Bugge and Aaskow, 1761}

Bredal published two versions of his poem in honour of Bugge and Aaskow. The first is dated Trondheim, 6 June 1761, a date which is probably correct, since it was published in the Copenhagen newspaper Kiфbenhavns Adresse-Contoirs Efterretninger already Friday 19 June. Given the time it would take for a letter to reach Copenhagen, composition immediately after the transit is quite plausible. A few days later, however, a revised and slightly longer version of the poem was published in an appendix to the Copenhagen weekly, Kiøbenhavnske Nye Tidender om laerde Sager. The first version had figured on the very first page of the 
Adresse-Contoir, without any explanation or comment whatsoever apart from that which is given in the Latin heading itself. The second version, however, was introduced by the following editorial remark:

Since the copy of Mayor Bredal's poem to Messieurs Bugge and Aaskow, which was presented last Saturday in the Adresse-Contoir, had arrived from the author in an incomplete and incorrect state, we have the honour to communicate to our readers the same poem correctly and completely. ${ }^{11}$

Comparing the two texts, one immediately recognizes that the second version is longer consisting of 20 instead of 16 elegiac couplets.

The poem opens with a description of the "clockwork" of the universe; every object follows its own path through the sky (vv. 1-2). The poet then turns to Venus with an apostrophe ("Tu, Venus alma!" v. 4), which soon takes the form of a complaint against her elusive nature. The goddess constantly changes form from Evening Star to Morning Star, she may all of a sudden borrow the light of the Sun to grow deceptive horns, etc. Then the rare phenomenon of a Venus transit is introduced, again in the second person singular: "Tunc propriam prodis Naturam, in lumina Phoebi [i.e., the Sun] / Ceu macula immergens" (vv. 15-16; the comparison to a sunspot is actually quite precise). The breakthroughs of theoretical astronomy since the days of Kepler are summarized through personifications of the human intellect's ability to establish laws of planetary motion ("scrutans solertia leges", v. 17) and the meticulous art of calculating astronomical tables ("præscia cura", v. 20). The elusive, deceitful goddess is thus "overcome" by means of scientific Enlightenment. The weather gods, however, could not be stripped of their power in the same manner, a problem that the next, desperate apostrophe bears witness to: "Aura fave!" (vv. 23-24). As the Sun ("Phoebus", invariably used by Bredal in place of Helios) finally emerges, its wagon turns out to be ugly, the horizon polluted by clouds (vv. 25-26). The first version breaks off shortly before time is running out. The poet encourages the heroes nonetheless to persevere: "En vigilis noctis præmia qvanta valent?" is the final, rhetorical question (v. 32). The second version continues with the Sun suddenly bursting forth through the clouds, just as the tiny black spot of Venus is about to leave the disc of the Sun: "En globus e disco luminis ater abit!" (v. 36). Accordingly, the poet calls the observers to hurry back to their instruments, so that they at least can record the very end of the transit, which is far better than nothing.

Closer examination of the two versions reveals that although the general narrative is the same, several words, even entire lines, have been modified in the second version. It seems obvious that the version in Nye Tidender represents the poet's "second thoughts", dispatched to Copenhagen shortly after the first version had prematurely been submitted to the AdresseContoir. I have therefore chosen to follow the second version closely, placing variant readings from the Adresse-Contoir in the apparatus. The orthography used by Nye Tidender is retained, although some punctuation has been standardized. Digitized versions of both newspapers are now freely available on the internet, so the originals can easily be consulted. ${ }^{12}$ 


\title{
Text Poem 1
}

\section{SIGLA}

$\mathbf{A}=$ The version printed in Kiøbenhavns Adresse-Contoirs Efterretninger (Bredal 1761a); contains lines $1-32$

$\mathbf{L}=$ The version printed in Kiøbenhavnske Nye Tidender om lærde Sager (Bredal 1761b);

contains lines $1-40$

\author{
Amicis \\ summo honore suspiciendis \\ scientiæ astronomicæ peritis \\ Dominis \\ BUGGE et AASKOV, \\ Ad Nidrosiam \\ Veneris Solem transeuntis videndæ gratia \\ iter facientibus \\ per iniuriam nebulosæ athmosphæræ \\ ut plurimum spe frustratis \\ inter otia \\ has lineolas posuit \\ N. K. Bredal.
}

Dum peragit coeli vel sol vel terra diurnas

Miro Errore Vias, stellaque quæque suam;

En rutilis alias facibus spectabile Sidus

$\mathrm{Tu}$, Venus alma! tuam ducis in orbe viam.

Coelestis Proteus! Phœbum sequerisque fugisque

Hespere, cum sequeris; Phosphore, quando fugis.

Jam mentita facem vicini Solis ab igne

Fulges, mendico lumine tota calens.

Jam, veluti Divæ pro more Triformis, in umbra

Dum partim resides, cornua parva geris.

Mox Oculos fallis, vertensque ad lumina Solis

Grata iterum lucem, das, recipisque simul.

Contingit raro (sæpe hoc contingere posset)

Quod medium tangas in statione Locum.

Tunc propriam prodis Naturam, in lumina Phoebi

Ceu macula immergens invidiosus honos!

Has novit dudum, scrutans solertia leges,

Et motum Coeli conjicere inde potest.

Hinc numerata Dies, præscribit cuilibet horam

Phoenomeno Coeli præscia cura suam. 
Et foret hoc anno propria spectabilis umbra

Errans forte Venus, si modo visa foret.

Aura fave! Nigrosque reduc de cardine Coeli

Invidiosa imbres; quæsumus! Aura fave!

Heu! Nunc Oceano surgit pollutus horizon

Nubibus, et foedo syrmate Phoebus adest.

Phoebus adest comitis tenebrosi vertice tinctus;

Ast prohibent nubes cernere lucis iter.

Ter cupiit frustra vetitum protrudere lumen;

Ter Sparsa insequitur nubila tota cohors.

Ite Viri! Spes grandis abest fere Perdita cura est;

En vigili nocti præmia quanta valent!

Ast perstate Viri! factum probat exitus omne

Per spissos nimbos Lux inopina venit.

Ecce suos prodit Phoebus per nubila currus

En globus e disco luminis ater abit!

Finem Phoenomeni jam fas est cernere rari

Delusa nondum spe properate Viri!

Est quoddam prodire tenus; dum non datur ultra.

Dimidium facti, qui bene finit, habet.

Titulus sicut in $\mathbf{L}$ Ad Amicos / summo honore suspiciendos / Dnos. BUGGE \& AASKOV, / ad Nidrosiam, Veneris videndæ gratiâ, iter fa- / cientes per injuriam nebulosæ Athmo- / sphæræ spe frustratos, / inter otia has lineas posuit / N. K. Bredal. / Nidrosiæ / d. 6 Jun. 1761 A $\mid \mathbf{2}$ suam $\mathbf{L}$ suas $\mathbf{A} \mid \mathbf{4}$ sic interpungit $\mathbf{A}$ Tu Venus alma $\mathbf{L} \mid \mathbf{6}$ cum $\mathbf{L}$ dum $\mathbf{A} \mid \mathbf{8}$ Fulges, mendico lumine tota calens $\mathbf{L}$ Fulges, \& mutuo lumine tota cales $\mathbf{A} \mid \mathbf{9}$ veluti Divæ pro more Triformis $\mathbf{L}$ velut ad morem Divæ triformis $\mathbf{A} \mid \mathbf{1 0}$ partim $\mathbf{L}$ propria $\mathbf{A} \mid \mathbf{1 1}$ vertensqve $\mathbf{L}$ vertisqve $\mathbf{A} \mid \mathbf{1 2}$ das recipisque $\mathbf{A}$ das, recipisquæ $\mathbf{L} \mid \mathbf{1 5}$ propriam prodis Naturam, in lumina $\mathbf{L}$ Insitam prodis naturam, Lumina A | 16 immergens invidiosus $\mathbf{L}$ obsedes; invidiosus $\mathbf{A} \mid \mathbf{1 7}$ Has novit dudum, scrutans $\mathbf{L}$ Novit jam dudum sagax A | $\mathbf{2 4}$ Aura fave! L Aura fave. A | 28 Ast L Sed A | 29 Ter cupiit frustra L Nititur heu! frustra A | 30 Ter Sparsa L Sparsa, sed A | 31 Spes grandis abest fere Perdita cura est $\mathbf{L}$ Spes omnis abest \& Perdita cura A | 32 En vigili nocti præmia quanta valent! L En vigilis noctis præmia qvanta valent? A | 34 nimbos scripsi nimbros $\mathbf{L}$

\section{Translation Poem 1}

To his friends, Mister Bugge and Mister Aaskow, well versed in the science of astronomy and worthy of the highest esteem, N.K. Bredal wrote in his spare time these modest lines, at the time when they undertook a journey to Trondheim in order to observe the transit of Venus in front of the Sun's disk, only to find that most of their hopes were in vain. 
Whilst the Sun and the Earth carry out their daily

Voyages through the heavens, as well as each star its own;

Look! There you are, otherwise so spectacular with your reddish gleam,

Venus the gracious, following your own path through the universe.

You heavenly Proteus! You chase, and you flee from, Phoebus:

As Hesperus, when you chase; as Phosphorus, when you flee.

All of a sudden you shine with a torch that you have stolen from the fire of the Sun, your neighbour;

Ablaze all over your body with a shimmer that is false and deceitful.

Then, in the style of the three-guised Goddess, you retreat

To the shadows, though only in part, carrying tiny horns.

Soon after, you deceive the eye of the beholder by seemingly returning to Phoebus

His joy-bringing rays: simultaneously, you give and you receive.

It happens rarely (it could have come to pass quite frequently)

That you graze the centre in your positioning.

Finally, you then betray your own nature, by immersing yourself in the rays

Of Phoebus, in the form of a spot, a hateful honour!

Cunning intelligence had found this out long ago, in its scrutiny of the laws,

From which the motions of the heavens can be perceived.

Hence, the day had been calculated; prudent foresight prescribes

To each and every phenomenon in the heavens its own proper time.

And this was the year when Venus was to be observable in the midst of her wanderings

Thanks to her own shadow, if only she were there to be seen.

Wind, would you please be so kind as to drive back from the odious roof of the sky

Those dark rainshowers - we beg you, be kind!

Oh, no! Up from Oceanus there now rises a horizon polluted

By clouds. Phoebus has come, in a dirty wagon.

Phoebus has come, tainted by the vortex of a shadowy companion.

And yet, the path of his light is impossible to discern because of prohibiting clouds.

Three times did the rays try in vain to protrude through the clouds;

Three times did the entire cloudy band gather to prevent them.

Persevere, you men! The great hopes are broken, nearly all preparations were in vain.

Now look what they are worth, the profits that came out of a night without sleep!

And yet, do not give up! All deeds are judged by their ending.

All of a sudden, light breaks through the dense clouds.

Behold! There he is, Phoebus betrays his wagon through the layer of cloud;

And look, there is that tiny black spot, about to leave the disk of the light!

Now the right thing to do is to observe the end of this rare phenomenon;

Make haste, you men! All hope is not gone quite yet.

It is not without value to produce something small, if something more is not possible.

He who finishes well, has made half an achievement, at least. 


\section{2: For Kratzenstein, 1769}

Whereas Bugge and Aaskow at least witnessed the very end of the transit, Kratzenstein's observation eight years later was a complete failure. However, this does not mean that his expedition was worthy of oblivion. The 13 elegiac couplets begin by introducing a horrific scene, "horresco referens" (v. 3), in which the hero of the poem (Kratzenstein) faces a heavy North wind and rain showers during the evening of $3^{\text {rd }}$ June. The rain continues through the entire night, leaving no chance to see the objects of the sky ("Sidera", v. 8) that he so desperately needs to observe. At dawn, "Aurora refulget" (v. 15), but the observer still struggles in vain to see anything at all as rain continues. Eventually, the goddess from Cythera (Venus) has left the disk of Phoebus (the Sun), intending to stay away for more than a hundred years ("ultrà viginti Lustra", v. 20). The tragic mood is then broken with a plea that the gods have bestowed good weather on observers stationed close to either of the Earth's poles - a reference to the need for corresponding observations from both ends of the world in order to calculate the true size of the solar system. If that happens, the hero will leap to the zenith of the sky with joy! (v. 25). Unlike the other two Venus transit poems, the entire poem is written from Kratzenstein's perspective - he is the first person singular of this poem.

As will be seen below, Bredal indicates that the poem was written "rogante ... D[omi]no Kratzenstein". Kratzenstein obviously remembered Bredal's poem to Bugge and Aaskow, and felt that his own efforts to observe Venus should be immortalized in a similar manner. However, the poem was not printed in any of the leading Danish newspapers, nor in Trondheim's own Tronhiems Adresse-Contoirs Efterretning, issued since 1767. Instead, Bredal presented the manuscript to Father Hell, who probably planned to include it in his grand Expeditio litteraria ad Polum arcticum. Towards the end of his life, when Hell realized that this work would never materialize, he started publishing fragments of it in his journal, the Ephemerides Astronomicae. The first "fragment" includes the poem for Kratzenstein along with the poem for Hell himself (Hell 1790, 359-361). For the printed version, Hell made some changes in Bredal's manuscript. These changes were mostly followed verbatim in the printed version. However, Hell seems to have copied the text in another (lost) manuscript, which was sent to the printer. In this lost manuscript, Hell added some explicatory footnotes ${ }^{13}$ and perhaps made further alterations as well, viz. standardization of capital letters at the start of all nouns and use of capitals for names of Greco-Roman Gods (see the apparatus criticus). In editing the poem, I have followed Bredal's original, although comparison with a digitized version of the manuscript, which is now freely available on the internet, ${ }^{14}$ will show that some punctuation has been tacitly altered. I have not listed variants of punctuation, nor orthographic conventions such as Coeli versus Coeli. 


\title{
SIGLA
}

$\mathbf{B}=$ Bredal's own manuscript (Bredal MS 1)

$\mathbf{H}=$ Corrections and additions in Hell's hand on the same manuscript

$\mathbf{E}=$ The version printed in the Ephemerides Astronomicae (Hell 1790)

\author{
Elegia \\ in Diem $3^{\text {um Junii } 1769 .}$
}

Cum subit istius tristissima Noctis Imago

qvâ Venus in Phoebi Sidere visa foret;

Horresco referens, surgunt Moerore Capilli, nam renovatus habet tanta Alimenta Dolor.

Hev! spissæ Nubes, mixtiqve Aqvilonibus Imbres

insolitum prohibent cernere Phoenomenon.

Hora venit ... Lentiqve Oculos obvolvo fideli;

Sidera, qvæ petii, densior Umbra tegit.

Non licuit totô dignoscere Sidera Coelô,

Luminis hev! Phoebus Fons et Origo latet!

Nocte pluit totâ; ... frustrà Spectacula manè

qværuntur; Coeli tristis Imago fuit.

Ter Vitra amplector (qvid enim tentasse puderet?);

De lassis Manibus ter mihi Vitra cadunt.

Conor adhuc, momenta premunt, Aurora refulget,

Lumine sed dubiô, vix mihi nota Sitû.

Spes aberat ... Cytheræa suum trans Lumina Phoebi

consummavit Iter, non reditura citò.

(Et rediens facias Spectacula digna Nepotum

ultrà viginti Lustra videnda Venus!)

Solamen superest: socios habuisse Laborum;

Naufragii socios non habuisse juvat.

Forte fuit, spero, minus invidus aër ad Arcton, et favit Votis Sol sub utrôqve Polô.

Tunc feriam rediens sublimi Vertice Coelum.

Forte suos habeant hæc mea Vota Deos.

Nidrosiæ

d: $4^{\text {ta }}$ Junii

1769.

Rogante celeberrimô D ${ }^{\text {no }}$ Kratzenstein 
hasce lineolas posuit

N: K: Bredal.

Titulus sicut in B qua cel. D. Kratzenstein, Professor Hafniensis, suscepto periculoso maritimo itinere Nidrosiæ (Drontheimii) observatione Transitus Veneris, coelo adverso, privatus est addit $\mathbf{H}$ ELEGIA in diem 3 Junii 1769, qua cel. D. Kratzenstein, Professor Medicinæ Hafniensis \& Astronomus exercitatissimus, suscepto periculoso maritimo itinere, observatione Transitus Veneris Nidrosiæ seu Drontheimii, caussa cœli nubibus obducti, privatus fuit $\mathbf{E} \mid \mathbf{2}$ Venus in Phoebi BH VENUS in PHOEBI E 7 Lentique Oculos obvolvo B Vitroque .. obarmo $\mathbf{H}$ Vitroque oculos obvolvo $\mathbf{E} \mid \mathbf{1 0}$ Phoebus B (Phoebus) $\mathbf{H}$ (PHOEBUS) $\mathbf{E}$ | 15 momenta BH Momenta E | 17 Cytheræa .. Phoebi BH CYTHERÆA .. PHOEBI E | 1920 (Et .. Venus!) BH Et .. VENUS. E | 21-22 socios bis BH Socios bis $\mathbf{E} \mid \mathbf{2 3}$ aër BH Aër $\mathbf{E} \mid$ Subscriptum sicut in B Nidrosiæ BH Nidrosiæ / (seu Drontheimii) E D ${ }^{\text {no }}$ Kratzenstein BH Domino / Kratzenstein $\mathbf{E}$ hasce BH has E Urbis Nidrosiensis Præfectus Civium sub nomen Bredal addunt $\mathbf{H E}$

\section{Translation Poem 2}

Elegy for the $3^{\text {rd }}$ day of June, 1769

The extremely sad image of that night arose,

That night, in which Venus was to be observed on the star of Phoebus;

I shiver when telling the story, the hair on my neck turns bristly,

Such is the nourishment sorrow finds as it is renewed by its recollection.

Oh no! Dense clouds, and rainshowers mixed with northerly stormwinds

Prevented the phenomenon from being observed.

The time of the clock had come. I let my eye disappear in the faithful ocular;

However, a shadow too thick covered the starry objects that I searched for.

It was impossible to see any object at all anywhere in the sky;

The origin and source of the light, Phoebus, was woefully hidden!

The rain fell all night. In the morning, the heavenly spectacles

Were searched for again, but the face of the sky was sad as ever.

Three times I grabbed hold of the ocular (what shame could there be in attempting?);

Three times the ocular fell from my exhausted hands.

I still did not cease trying. Time was flying fast, Aurora was returning with her splendour,

Although her light was diffuse, and it was hardly possible for me to ascertain whence it came.

Hope was fading. The Goddess from Cythera had by now fulfilled her journey

Across the rays of Phoebus, hardly intent on returning there soon.

(And, Venus: when you return, please provide a spectacle worthy of a future generation, 
You who will not be seen again for more than twenty half-decades!)

Some comfort remains. Not to have been alone in the endeavours is a treat;

To have been the only one to experience a shipwreck, likewise.

Perhaps (I hope) the weather has been less malevolent further north in the Arctic,

And the Sun has been gracious towards our prayers beneath each Pole.

In that case, I will leap to the zenith of the sky with joy upon my return.

Perhaps these prayers of mine are making their way to the appropriate Gods at this moment?

Trondheim, June $4^{\text {th }}, 1769$

These versified trifles were produced upon request from the highly famous Mister Kratzenstein

by N. K. Bredal

\section{3: For Hell, 1769}

Bredal wrote his poem for Maximilianus Hell on the same sheet of paper as the poem for Kratzenstein. ${ }^{15}$ The poem for Hell consists of just six elegiac couplets, expressing nothing but joy. The "sweet friend" ("dulcis Amice!" v. 2) returns from the wilderness of the North. ${ }^{16}$ The dangers of the Arctic Ocean, with reefs and straits such as the famous maelstrom of Moskenes ("Freta", v. 3), the imposing mountains covered in perpetual snow, the darkness of the Polar Night - like a true Caesar, Hell has overcome them all ("venis ... vides ... vincis", vv. 7-8). The brave efforts of the hero have won the support of both Phoebus and Venus, as well as the gods of the wind and the sea. The Penates now await the hero; the poem ends with a prayer that the same (Greco-Roman) gods will guide him safely to his home.

When Hell corrected the poem before publication in the Ephemerides Astronomicae, he removed certain mock-heroic aspects. While the play on Caesar's "veni vidi vici" remained underscored, the claim that Hell had seen "omne ... qvod erat notabile Visû" (v. 7, probably an allusion to his over-ambitious plan for a work on "everything" regarding the far north) became reduced to the more modest "omne ... qvod erat visibile in Astris" (or "spectabile in Astris" in the printed version). There may be a metrical reason behind this: Bredal's version requires the pronunciation notabile, which does not correspond to classical prosody. Another amendment is Hell's elegant change from the metrically impossible "Nivibus æternis" to the unequivocal, but metrically correct, "Æternis nivibus" (v. 6; "Æternis Nivibis" in the printed version). ${ }^{17}$ I have retained Bredal's original, giving Hell's alterations in the apparatus, except for the last-mentioned correction by Hell, which I have followed. On some occasions, I have altered the punctuation, compare my introduction to the poem for Kratzenstein above. 
Text Poem 3

\section{SIGLA}

$\mathbf{B}=$ Bredal's own manuscript (Bredal MS 1)

$\mathbf{H}=$ Corrections and additions in Hell's hand on the same manuscript

$\mathbf{E}=$ The version printed in the Ephemerides Astronomicae (Hell 1790)

Ad

Celeberrimum $\mathrm{D}^{\text {num }}$ Hell

Iam qvid habent veri Vatum Præconia, cernis,

Votorum compos, dulcis Amice! redis.

Te Freta non terrent, non terrent naufraga Saxa,

Non Glacie strictus Pontus et Umbra Poli.

Non Iter impediunt vestiti Nubibus Alpes,

Æternis nivibus nonqve senilis Hÿems.

Tu venis, omne vides, qvod erat notabile Visû, obstantesqve tibi vincis utrinqve Deos.

Faverunt dignis Phoebus, Venus, Æolus ausis, et qvæ Neptunus Numina cuncta regit.

Gratulor; incolumis proprios invise penates; jam qvoqve nunc habeant hæc mea Vota Deos.

Nidrosiæ

d: $1^{\text {mo }}$ Septembr.

$\mathrm{N}: \mathrm{K}$ : Bredal

1769

Titulus sicut in B Ad / Celeberrimum $\mathrm{D}^{\text {num }}$ Maximil. Hell, Wardoehusio Nidrosiam (Drontheimium) obtenta feliciter observatione Transitus Veneris, reducem $\mathbf{H}$ Ad / Dominum MAXIMILIANUM HELL / Wardoehusio Nidrosiam (Drontheimium) obtenta felici- / ter observatione Transitus Veneris reducem, ab eodem / Domino Bredal E | 6 Æternis n[N]ivibus HE Nivibus æternis $\mathbf{B} \mid \mathbf{7}$ notabile Visû $\mathbf{B}$ visibile in Astris $\mathbf{H}$ spectabile in Astris $\mathbf{E} \mid \mathbf{9 - 1 0}$ Phoebus, Venus, Æolus .. Neptunus B $\underline{\underline{\text { Phoebus}}}, \underline{\underline{\text { Venus}}}, \underline{\underline{\text { Eolus }} \text {.. Neptunus }} \mathbf{\text { H litteris }}$ capitalibus E | 11 penates B Penates HE | Subscriptum sicut in B idem qui supra sub nomen Bredal addunt $\mathbf{H E}$ 


\section{Translation Poem 3}

To the highly famous Mister Hell

What truth there is in the declarations of prophets, you now know,

My sweet friend! You return, having achieved what you prayed for.

Narrow straits do not scare you, nor shipwrecking reefs;

Neither the ice-covered sea, nor the polar winter nights.

The Alps dressed in fog, the long-lasting winter with its eternal masses of snow;

None of that is capable of preventing your voyage.

You come, you see everything that is worthy of being observed;

You conquer the Gods that are up against you from either side.

The heroic endeavour was favoured by Phoebus, Venus, and Aeolus,

As well as by all the spirits that Neptune has under his sway.

I congratulate you! Now safely return to visit the Penates of your own:

May the Gods hear my prayers this time as well!

Trondheim, September $1^{\text {st }}, 1769$

N. K. Bredal

\section{Epilogue, or: Astronomy, Latinity, Enlightenment}

I have tried to show that Niels Krog Bredal was a many-sided character with broad, cosmopolitan interests that transcended both theatre and belles lettres - and the DanoNorwegian cultural context as such. It is well known that Bredal's university exams were in jurisprudence. However, a notebook that has hitherto escaped notice demonstrates that during his student years, he followed courses in astronomy and other natural sciences as well. Initially, lectures by Christian Horrebow, Copenhagen's professor of astronomy and Astronomer Royal, filled most of his notes. However, even after finishing his studies, Bredal took excerpts from literature on medicine, meteorology, natural history, etc. - all this in clear, straightforward Latin prose (Bredal MS 2). According to the title page of this 240-page manuscript, the notes have been made both in Copenhagen (presumably during the 1750s) and in Trondheim (in the 1760s). It is telling that Bredal never switched language for his notebook. He clearly read several modern languages, including French, Italian, English, German, Swedish, and of course Danish. When it came to the hard sciences, however, Latin appears to have been his preferred tongue.

Bredal's close relationship to the Latin language is visible also in other contexts, such as when he, in a letter to an old friend who had just returned from a Grand Tour abroad, joked 
about his own status as bachelor. Whereas all preceding Trondheim mayors were buried with tombstone inscriptions like, "Natus A[nn]o ... Maritus A[nn]o [...] reliquit Filios et filias" [born in the year ... married in the year ... he left behind the following sons and daughters], on Bredal's tomb he suggested the following epitaph:

Hic jacet Bredal,

Poëtaster spontaneus,

Consul involuntarius,

invitis Musis

Musis deditissimus etc. ${ }^{18}$

[Here lies Bredal, / self-induced versifier, / unwilling mayor, / to the dismay of the muses / to the muses highly devoted, etc.]

Ostensibly, the littérateur Niels Krog Bredal was part of a Dano-Norwegian "cultural awakening". With his proud emulation of foreign forms of theatre in the Danish language, and with his use of episodes from national history for the play Gram og Signe, he was clearly a patriot in word and deed. His Venus transit poems are, for their part, inscribed into the more cosmopolitan ideology of the Respublica litteraria, an "imagined community" of natural philosophers collaborating for the advancement of universal knowledge, based on a panEuropean heritage transgressing both national and confessional boundaries (e.g. Bots and Waquet 1997). Latin poetry was in itself a sign of intellectual capacity. Moreover, it was a way to give events of the present an air of "immortality" and "universality": immortality, in the sense that Latin verses evoked the ancient masterpieces of European literature;

universality, insofar as the Latin language served as a lingua franca for all nations in which the exact sciences flourished (Aspaas 2014). An implicit message underlying Bredal's Venus transit poems is thus evident. The Oldenburg Monarchy, and Trondheim in particular, took part in a grand, international, historic collaborative enterprise. The individual participants of this heroic endeavour should not be forgotten, even though the weather was not always propitious.

Attitudes towards language were complex during the European Enlightenment. Bredal himself gives voice to this complexity in the prefaces to two of his works from the 1750s, the abovementioned Gram og Signe and Ovidii Nasonis Metamorphoses. The former work was written in full awareness of the supreme position of the Italian language within the opera. However, since certain French, English, and German Singspiele had been produced of late, Bredal presented his own attempt in the hope "that our Danish language shall regain its forlorn citizenship at the Skueplads". ${ }^{19}$ Furthermore, "the love of my mother tongue has been the only inspiration, which has steered my spirit and guided my pen". ${ }^{20}$ There are unfortunately no paratexts to Bredal's Latin poems that elucidate his use of the Latin language. His translation of Ovid, however, contains a preface with some interesting remarks. ${ }^{21}$ The 1758 edition was dedicated to the Art School (Kunstakademiet) in Copenhagen. Many artists had not learned the classical languages, yet the classics were translated into more and more European languages and deserved to be made accessible to Danish artists as well. Bredal continues: 
I hope the benevolent reader - partially in recognition of the general difficulty of translating from verse to verse, but even more so in consideration of the spirit of the original and the supreme richness of the Latin language, which surpasses all other languages in this respect will excuse any errors that an unfortunate translator may have committed. ${ }^{22}$

The rationale behind the two prefaces may perhaps be summarized in the following manner. The Danish tongue is to be patriotically cultivated at the Danish stage and the country's artists are to be inspired through Danish translations of the ancient classics. All this conceding that the Latin language is "richer" than any other language in the world and, by implication, a language well worth mastering. Nevertheless, by the second half of the eighteenth century, the use of Latin for artistic purposes was in rapid decline in the Kingdom of Denmark of Norway (Schepelern 1979; Skafte Jensen 2014b). Within the natural sciences, however, Latin still had a strong standing internationally. It is telling that one of the leading periodicals of astronomy, the Ephemerides Astronomicae ad Meridianum Vindobonensem founded by Hell, was issued in Latin until well into the nineteenth century (cf. Sommervogel 1893). Via the Latin language, a close bond between Astronomy and Antiquity, and between progressive Enlightenment and traditional Erudition, was preserved. An able astronomer was expected to be a person of learning, consciously standing on the shoulders of a series of giants reaching all the way back to Greco-Roman Antiquity. To write Latin poems in praise of astronomers was thus quite logical.

In a different context entirely, the Neo-Latinist and intellectual historian Dirk van Miert has discussed the choices between Latin and the vernaculars in early modern Europe. Examining the correspondence of Joseph Scaliger, van Miert points out that "efforts to promote a 'national identity' were directed not only towards the writer's own group, but towards people of other nations" as well. In order to impress this larger public, Latin was, paradoxically, often preferred over vernacular languages (Miert 2010, 11). By using Latin for his poetry in praise of contemporary astronomers, Bredal by no means undermined the cultural politics of the Oldenburg Monarchy. Instead, he patriotically sought to vindicate the place of DenmarkNorway within the pan-European Republic of Letters. The Danophone and the Latinate Bredal should not be seen as opposites. Instead, they are two faces of the same coin.

\section{Acknowledgements}

I thank the editor of Symbolae Osloenses and the anonymous reviewer for their suggestions of improvement of my paper, and my parents, Ragnhild Nilstun and Øystein Aspaas, for correcting English of the final manuscript version. 


\section{References}

Aarset, Hans Erik. 1999. “'Indrettet som en pastorelle': Streiftog i Niels Krog Bredals 'hellenistiske' musikk-dramatikk." In Mellom europeisk tradisjon og nasjonal selvbevissthet: Det norsk-klassiske drama, 1750-1814, edited by Rolf Gaasland and Hans Erik Aarseth [sic], 52-78. Oslo: Spartacus.

Akujärvi, Johanna. 2010. ““...til Rusin-Strutar och Tortebotnar’: Översättningars nytta enligt förord till svenska översättningar av antik litteratur under 1700-talets första hälft.” Sjuttonhundratal: Nordic Yearbook for Eighteenth-Century Studies 7: 50-73. http://dx.doi.org/10.7557/4.2467

Aspaas, Per Pippin. 2010. "Le Père Jésuite Maximilien Hell et ses relations avec Lalande." In Jérôme Lalande (1732-1807): Une trajectoire scientifique, edited by Guy Boistel, Jérôme Lamy, and Colette LeLay, 129-148. Rennes: Presses universitaires de Rennes.

Aspaas, Per Pippin. 2011. "Nordiske amatørastronomers bidrag i forbindelse med venuspassasjene 1761 og 1769." In Mellom pasjon og profesjonalisme: Dilettantkulturer $i$ skandinavisk kunst og vitenskap, edited by Marie-Theres Federhofer and Hanna Hodacs, 103127. Trondheim: Tapir.

Aspaas, Per Pippin. 2012. Maximilianus Hell (1720-1792) and the Eighteenth-Century Transits of Venus: A Study of Jesuit Science in Nordic and Central European Contexts. PhD dissertation. Troms $\varnothing$ : University of Troms $\emptyset$. http://hdl.handle.net/10037/4178

Aspaas, Per Pippin. 2013. "Denmark-Norway, 1761-1769: Two missed opportunities?” The Journal of Astronomical Data 19,1 = Meeting Venus: Proceedings of the Venus Transit Conference, Troms $\phi$ 2012: 39-48. http://hdl.handle.net/10037/5195

Aspaas, Per Pippin. 2014. "The Use of Latin and the European Republic of Letters: Change and Continuity in the Seventeenth and Eighteenth Centuries." Nordlit $33=$ Libellus festivus Sunnivae des Bouvrie dedicatus: 281-295. http://dx.doi.org/10.7557/13.3169

Aspaas, Per Pippin. (forthcoming). "Nicolai Krog Bredal ONEIPO-KO $M O \Sigma$. Id est Mundus in Somnio, Poëma Philosophico-Heroicum (Haffniae, 1753): Editio diplomatica, praefatione notisque instructa."

Behrend, C. 1911. “To Breve fra Niels Krog Bredal.” Personalhistorisk Tidsskrift 32: 59-66.

Bliksrud, Liv. 1999a. "Bredal, Niels Krog.” In Norsk biografisk leksikon, edited by Knut Helle et al., vol. I, 447-448. Oslo: Gyldendal.

Bliksrud, Liv. 1999b. Den smilende makten: Norske Selskab i Kфbenhavn og Johan Herman Wessel. Oslo: Aschehoug.

Bliksrud, Liv. 2010. “Tilfellet Bredal - Et bidrag til norsk resepsjonshistorie.” Edda 110,3: 244-257. 
Bull, Francis. 1916. Fra Holberg til Nordal Brun: Studier til norsk aandshistorie. Kristiania: Aschehoug.

Bots, Hans, and Françoise Waquet. 1997. La République des Lettres. Paris: Belin.

Bredal MS $1=$ [Poems for Kratzenstein and Hell, in Bredal's own hand, with editorial additions by Hell] Institut für Astrophysik der Universität Wien, Vienna. Chr. 90. Manuscripte von Hell. 2 pp. Digitized version at http://dx.doi.org/10.18710/YGK7CO.

Bredal MS 2 = Excerpta Elementa miscellanea Philosophice Naturalis experimentis plerumqve illustrata, adjectis qvibusdam in Collegio Doctissimi D[omi]ni Christiani Horrebovii dictatis collecta à Nicolao Bredahl. Hafnice, et Nidrosia collecta. Kongelige Bibliotek, Copenhagen. MS Thott $4^{\circ}, 643.240$ pp.

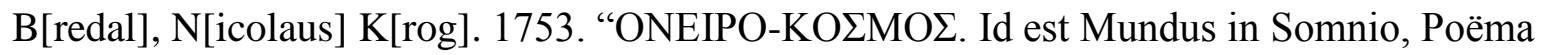
Philosophico-Heroicum.” Nye Tidender om Larde og Curieuse Sager No. IX, den 2 Mart.: 66-71.

Bredal, Niels Krog. 1756. Gram og Signe, eller Kierligheds og Tapperheds Mesterstykker: Et Synge-Spil i trende Optog. Copenhagen.

Bredal, Niels Krog. 1758. Publii Ovidii Nasonis Metamorphoses: Oversatte i Danske Vers. [Copenhagen].

Bredal, N[icolaus] K[rog]. 1761a. “Ad amicos summo honore suspiciendos Dnos. Bugge \& Aaskov, ad Nidrosiam, Veneris videndæ gratiâ, iter facientes per injuriam nebulosæ Athmosphæræ spe frustratos, inter otia has lineas posuit N. K. Bredal.” Kiфbenhavns AdresseContoirs Efterretninger No. 45, Fredagen den 19 Junii: 353.

Bredal, N[icolaus] K[rog]. 1761b. "Amicis summo honore suspiciendis scientiæ astronomicæ peritis Dominis Bugge et Aaskov, ad Nidrosiam Veneris Solem transeuntis videndæ gratia iter facientibus per iniuriam nebulosæ athmosphæræ ut plurimum spe frustratis inter otia has lineolas posuit N: K: Bredal.” Kiøbenhavnske Nye Tidender om larde Sager Num. 25, Torsdagen den 18de Jun., Anhang: 203-204.

Bredal, N[iels] K[rog]. 1762. Hr. Joh. Andr. Cramer, kongelig tydsk Hof-Pradikant $i$ Kiфbenhavn, hans Afhandling om Smaae-Koppernes Indpodning, eller Inoculationen, i tvende Stykker af den Nordische Aufseher; Nu paa Dansk oversat, samt forøget med adskillige Anmarkninger. Trondheim: Jens Christensen Winding.

[Bredal, Niels Krog.] 1767. Tanker efter Niels Klims Maade, eller en opmarksom reysende Amerikaners Efterretning, til en Borger i Maanen, om et vist Land og Folk paa vores Jordkugle. Befordret til Trykken af Hans Mikkelsens Halvbroder. Copenhagen: Paul Herman Hoecke.

Bredal, Niels Krog. 1768. “Tanker om Videnskabers og Indsigters Erhvervelse, for saavidt samme kan misbruges, og bruges paa rette Maade." Det Kongelige Norske Videnskabers Selskabs Skrifter 4: 270-287. 
Carlson, Marvin. 1975. "Rosenstand-Goiske and 'Den Dramatiske Journal': Scandinavia's first theatrical criticism." Scandinavian Studies 47,1: 18-35. www.jstor.org/stable/40917492

Ehrencron-Müller, Holger. 1925. "Bredal, Niels Krog.” Forfatterlexicon omfattende Danmark, Norge og Island indtil 1814, vol. II: 45-49. Copenhagen: Aschehoug.

Eriksen, Anne. 2010. “Koppeinokulasjon i Norge.” Historisk Tidsskrift [Oslo] 89,3: 345-366.

Falk-Jensen, A., and H. Hjorth-Nielsen. 1954. "Bredal, Niels Krog." Candidati og Examinati Juris 1736-1936: Candidati Politices 1852-1936: Candidati Actuarii 1922-1936, vol. I: 193. Copenhagen: Gad.

Friis, Aage. 1904. Bernstorffske Papirer: Udvalgte Breve og Optegnelser vedrørende Familien Bernstorff i Tiden fra 1732 til 1835, vol. I. Copenhagen / Kristiania: Gyldendal.

Gaasland, Rolf. 1999. "Verdien av Tronfølgen i Sidon.” In Mellom europeisk tradisjon og nasjonal selvbevissthet: Det norsk-klassiske drama, 1750-1814, edited by Rolf Gaasland and Hans Erik Aarseth [sic], 79-91. Oslo: Spartacus.

Gejrot, Claes, and Annika Ström. 1999. Poems for the occasion: Three Essays on Neo-Latin Poetry from Seventeenth-Century Sweden. Stockholm: Almqvist \& Wiksell.

Gorm Tortzen, Chr. 2013. “Ovids Metamorphoser i danske oversættelser.” Aigis

Supplementum II = Festskrift til Adam Bülow-Jacobsen: 1-60. http://adam.sc.ku.dk/aigis/ABJ/CGT.pdf

Halley, Edmond. 1717. "Methodus singularis quâ Solis Parallaxis sive distantia à Terra, ope Veneris intra Solem conspiciendæ, tuto determinari poterit: proposita coram Regia Societate." Philosophical Transactions of the Royal Society of London For the Years 1714, 1715, 1716, vol. XXIX, Number 348: 454-464. www.jstor.org/stable/103085

Helander, Hans. 2004. Neo-Latin Literature in Sweden in the Period 1620-1720: Stylistics, Vocabulary \& Characteristic Ideas. Uppsala: Uppsala University Press.

Hell MS $1=$ [draft of letter addressed to "Herrn Peter Tönder von Nordal Præsidenten in Drontheim"] Institut für Astrophysik der Universität Wien, Vienna. Chr. 90. Manuscripte von Hell. 2 pp.

Hell MS 2 = [draft of letter addressed to "H: Hagerupp ambtmann über Finnmarcken"] Institut für Astrophysik der Universität Wien, Vienna. Chr. 90. Manuscripte von Hell. 2 pp.

Hell, Maximilianus. 1790. “Observationes Astronomicæ Latitudinum, \& Longitudinum Locorum Borealium Daniæ, Sueciæ, Norwegiæ, \& Finnmarchiæ Lapponicæ per iter arcticum Annis 1768, 1769, \& 1770 factæ.” Ephemerides Astronomica ad Meridianum Vindobonensem Anni 1791: Appendix.

Holtzapfel, Helmut. 1979. Maximilian Hell SJ i Danmark: Et bidrag til Kirkens historie $i$ Danmark $i$ sidste halvdel af 18. århundrede. Würzburg. 
Høgel, Sten. 1980. "Niels Hansen og det danske syngespils opkomst." Musik \& Forskning 6: 80-129. http://dvm.nu/files/musik_forskning/1982/mf1982_02.pdf

Kontler, László. 2014. “The Uses of Knowledge and the Symbolic Map of the Enlightened Monarchy of the Habsburgs: Maximilian Hell as Imperial and Royal Astronomer (17551792)." In Negotiating Knowledge in Early Modern Empires: A Decentered View, edited by László Kontler, Antonella Romano, Silvia Sebastiani, and Borbála Zsuzsanna Török, 79-105. Basingstoke: Palgrave Macmillan.

Kragemo, Helge. 1960. "Pater Hells Vardøhusekspedisjon. Belyst ved Pater Sajnovič's dagbok 1768-1769.” In Vardфhus Festning 650 År: Jubileumsskrift, edited by G. I. Willoch, 92-125. Oslo: Generalinspektøren for Kystartilleriet.

Krogh, Torben. 1924. Zur Geschichte des dänischen Singspiels im 18. Jahrhundert. Copenhagen: Levin \& Munksgaard.

Lalande, [Jérôme de]. 1763. "Remarques sur les Observations du Passage de Vénus, Faites à Copenhague \& à Drontheim en Norwège, par ordre du Roi de Dannemarck." Histoire de l'Académie Royale des Sciences Année M.DCCLXI.: Mémoires: 113-114.

Marlot, Christophe. 2004. Les passages de Vénus: Histoire et observation d'un phénomène astronomique. Paris: Vuibert.

Miert, Dirk van. 2010. "Language and communication in the Republic of Letters: The uses of Latin and French in the correspondence of Joseph Scaliger." Bibliothèque d'Humanisme et Renaissance 72: 7-34.

Monrad, S. 1779. Epitaphium b. Nicolao Krog Bredal positum. Editio tertia. Niderosiae: Typis Vindingianis.

Nøtvik Jakobsen, Rolv. 2015. Gunnerus og nordisk vitenskapshistorie. Oslo: Spartacus.

Petersen, Jul. 1887. “Aaskow, Urban Bruun.” In Dansk biografisk leksikon, tillige omfattende Norge for tidsrummet 1537-1814, edited by C. F. Bricka, vol. I, 30-31. Copenhagen: Gyldendal.

Prevost, Pierre. 1805. Notice de la vie et des écrits de Georges-Louis Le Sage de Genève. Geneva: J. J. Paschoud.

Sajnovics MS = [Travel diary Vienna-Vardøhus and back, April 1768-August 1770] Institut für Astrophysik der Universität Wien, Vienna. Chr. 90. Manuscripte von Hell. 178 pp.

Schepelern, H. D. 1979. "Dansk latindigtning ca. 1200-1800: En oversigt.” Museum Tusculanum 34-35: 86-132.

Skafte Jensen, Minna, ed. 1995. A History of Nordic Neo-Latin Literature. Odense: Odense University Press. 
Skafte Jensen, Minna. 2014a. "Neo-Latin Literature: The Nordic Countries." In Brill's Encyclopaedia of the Neo-Latin World, edited by Philip Ford, Jan Bloemendal, and Charles Fantazzi, vol. II, 1098-1101. Leiden: Brill.

Skafte Jensen, Minna. 2014b. "Forskningen i dansk nylatin ca. 1970-2014: En oversigt." Danske studier 109: 249-269.

Skjelmo, Randi. 2013. "Utdanning av lærere for det nordlige Norge: De tidlige institusjoner i Trondheim 1717-1732.” Sjuttonhundratal: Nordic Yearbook for Eighteenth-Century Studies 10: 39-62. http://dx.doi.org/10.7557/4.2620

Sogner, Sølvi. 2003. "Fromhet styrker rikene.” In Norsk innvandringshistorie, edited by Knut Kjeldstadli, vol I, 240-258. Oslo: Pax.

Sommervogel, Carlos. 1893. "Hell, Maximilien.” In Bibliothèque de la Compagnie de Jésus ... Bibliographie vol. IV, 238-258. Brussels: Oscpar Schepens / Paris: Alphonse Picard.

Snorrason, Egill. 1974. C. G. Kratzenstein: professor physices experimentalis Petropol. et Havn. and his Studies on Electricity during the Eighteenth Century. Odense: Odense University Press.

Splinter, Susan. 2007. Zwischen Nützlichkeit und Nachahmung: Eine Biografie des Gelehrten Christian Gottlieb Kratzenstein (1723-1795). Frankfurt am Main: Peter Lang.

Ström, Annika, and Peter Zeeberg. 2015. "Scandinavia." In The Oxford Handbook of NeoLatin, edited by Sarah Knight and Stefan Tilg, 493-509. Oxford: Oxford University Press.

Voje Johansen, Nils. 2011. "Da venuspassasjer forandret verden.” Almanakk for Norge 199: 81-85.

Widmalm, Sven. 2013. "Science in Transit: Enlightenment Research Policy and Astronomy in Sweden." The Journal of Astronomical Data 19,1 = Meeting Venus: Proceedings of the Venus Transit Conference, Troms $\phi$ 2012: 21-32. http://hdl.handle.net/10037/5195

With Andersen, Håkon, Brita Brenna, Magne Njåstad, and Astrid Wale. 2009. Aemula lauri: The Royal Norwegian Society of Science and Letters, 1760-2010. Sagamore Beach, Mass.: Science History Publications.

Woolf, Harry. 1959. The Transits of Venus: A Study of Eighteenth-Century Science. Princeton, NJ: Princeton University Press.

Wulf, Andrea. 2012. Chasing Venus: The Race to Measure the Heavens. New York: Knopf. 


\title{
Notes
}

\begin{abstract}
${ }^{1}$ In all biographic literature prior to Liv Bliksrud's entry in Norsk biografisk leksikon (1999a), 6 September 1733 is stated as Bredal's date of birth. Bliksrud, however, writes that Bredal was born 6 September in the year 1732, without citing any sources for this change of year. In a contemporary Latin obituary written by Søren Monrad, one reads that Bredal "ante sextum et quadragesimum annum suum occiderit" [he passed away before his $46^{\text {th }}$ year], in other words, he died as a 44 year old, on 26 January 1778 (Monrad 1779, no page). I therefore consider 1732 a misprint.
\end{abstract}

${ }^{2}$ There are no monographs on Bredal. Short biographical notices are provided by Ehrencron-Müller (1925); Falk-Jensen and Hjorth-Nielsen (1954); Bliksrud (1999a); etc.

${ }^{3}$ Bredal (1756, no page): "for endogsaa deri at være dansk." All translations in this article are by the author.

${ }^{4}$ See Ehrencron-Müller (1925) for a comprehensive overview of Bredal's publications.

${ }^{5}$ Aarset $(1999,52)$ : “Innenfor det norsk-danske 1700-tallsdramaets verden var det neppe noen enkeltperson som i sin samtid hadde en så fremtredende posisjon som Niels Krog Bredal, men som likevel er blitt så ettertrykkelig glemt av ettertiden."

${ }^{6}$ For an assessment of the qualities of this translation, see Gorm Tortzen (2013). Ovid was a favourite of "Det norske Selskab", founded by Bredal in the 1770s (Bliksrud 1999b, 163-167).

${ }^{7}$ For general studies of the history of Nordic Neo-Latin literature, see Skafte Jensen (1995) and Helander (2004); see also the succinct surveys by Skafte Jensen (2014a) and Ström and Zeeberg (2015). Regarding occasional poetry in particular, Gejrot and Ström (1999) point to general trends during the seventeenth century, though they do not cover Latin poems from Denmark-Norway.

${ }^{8}$ In the period from 1717 to 1727, von Westen lived in Trondheim, where he established schools in the Sami language and also embarked upon several missionary expeditions to the same regions that Hell had just travelled through (e.g. Skjelmo 2013).

${ }^{9}$ As stated earlier, county prefect Hagerup accompanied Hell on his way north in the autumn of 1768. Hagerup was a close friend of Bredal's. During the winter of 1768/1769, Hagerup sent a letter from Alta to Hell in Vard $\varnothing$ to which he appended some verses by Bredal. Hagerup's letter has not been found, nor the verses themselves. Hell, however, in his answer to Hagerup complements on Bredal's poetry: "fur die überschikte shöne Verse des H: Bredal erstatte [ich] freündlichsten dank; H: Sajnovics wolte ein antwordt verfertigen, allein wir sind alhie mit anderen Ihro May[estät] dem allerbesten Könige Ruhm und Ehre bringenden arbeithen allzustark überhaüffet, und werden genöthiget dergleichen amusements auf andere Zeiten zu verschieben.” Towards the end of the letter, Hell invites Hagerup over to Vardø for a visit, returning to Bredal's poem in the following manner: "wenn ich die Ehre haben werden Euer hoch und Wohledl alhie ganz freündlichst zu embrassieren, so werden Euer hoch und Wohl-Edl den mir angezeigten verse gantz anderst bet[rachten?], es brauchet nichts [anders] alß die zwey characterisierende epitheta calidi, und frigidi zu versetzen so wird sich diese verse recht wohl zu meinen wahren Charactere schiken." (Hell MS 2, undated draft, written ca. April 6 ${ }^{\text {th }}$, 1769. Orthography of the original retained).

${ }^{10} \mathrm{~A}$ member of the Bernstorff family and nephew of the serving foreign minister E. H. Bernstorff, A. P. Bernstorff writes in a letter to his uncle, dated July $2^{\text {nd }}, 1768$, that "Le père Hell part dans deux jours par terre pour Drontheim, seul avec son compagnon [i.e. Sajnovics], M[essieurs] les savants d'ici n'ayant trouvé personne pour l'accompagner. Kratzenstein en est si indigné qu'il ira lui-même l'année prochaine à Drontheim y faire ses observations" (Friis 1904, 514).

${ }^{11}$ Editorial remark in Bredal (1761b, 203): "Da den Copie af Hr. Borgemester Bredals Vers til Mes. Bugge et Aaskov, recenseret i Løverdags i Adresse-Contoiret, var ufuldstændig og urigtig kommet fra Forfatteren; saa have vi den Ære her at meddeele vore Læsere samme rigtig og fuldstændig." Again, there is a puzzling reference to particular dates. The Adresse-Contoir came out twice weekly, on Mondays and Fridays, whereas Nye Tidender regularly came out once every week, on Thursdays. According to the front page, the Adresse-Contoir containing the first version of Bredal's poem was issued on Friday, not Saturday, $19^{\text {th }}$ June. The issue of Nye Tidender with the revised version was - again, judging from the front page - published on a Thursday, and $18^{\text {th }}$ June at that. However, the revised version was not part of the newspaper proper, but formed part of an undated Anhang (appendix). I guess that the Anhang was actually published a few days later, probably early in the next week, and that the editor's reference to a Saturday is simply a slip of the pen.

${ }^{12}$ At present, a scanning of Kiфbenhavnske Nye Tidender om laerde Sager vol. 1761 is found on Google Books, under the false tag "Dansk litteratur-tidende" (retrieved 3 December 2015). Kiфbenhavns Adresse-Contoirs Efterretninger vol. 1761 has been digitised by the State and University Library in Aarhus, Denmark: http://www2.statsbiblioteket.dk/mediestream/avis/list (also retrieved 3 December 2015). Unfortunately, there appears to be no persistent url leading directly to these items.

${ }^{13}$ See for example his footnote to the line "Solamen superest: socios habuisse Laborum" (v. 21): "Socii Laborum, observandi scilicet Transitus Veneris in Ditionibus Regis Daniæ, erant P[ater] Maximilianus Hell cum 
socio P[atre] Sajnovics, a CHRISTIANO VII. Vienna Wardoehusium evocatus, \& Dominus Horrebow Adjunctus Astron[omus] in specula Hafniensi (Frater cel[eberrimi] Dom[ini] Christiani Horrebow id temporis Astronomi Regii Hafniæ) qui in Insulam Nordlandiæ, Dunoes dictam, ablegatus, eodem fato, coeli nubili, quo D[ominus] Kratzenstein Drontheimii, observatione Transitus Veneris privatus est" (Hell 1790, 360). For more on the brother of the Astronomer Royal, whose full name was Peder Horrebow the Younger, and his expedition to Dønnes on the island Dønna in Nordland County, see Aspaas (2013) or Voje Johansen (2011). Even Peder Horrebow's team passed by Trondheim en route between Nordland and Copenhagen. It is not known, however, whether Bredal wrote any poetry in commemoration of their efforts.

${ }^{14}$ See http://dx.doi.org/10.18710/YGK7CO.

${ }^{15}$ Bredal MS 1. Digitized at http://dx.doi.org/10.18710/YGK7CO.

${ }^{16}$ The epithet was certainly not ironic, to judge from one of Hell's letters from Vardø, dated 16 January 1769.

Listing a set of people in Trondheim that he wishes to receive his greetings, Hell characterizes mayor Bredal as "meinen besonderen hertzenfreund". (Hell MS 1, letter to Peter Tønder Nordahl in Trondheim).

${ }^{17}$ For further examples of metrical flaws in Bredal's Latin poetry, see Aspaas, forthcoming.

${ }^{18}$ Bredal's letter (in Danish, but with Latin phrases here and there) to Christian Martfeld in Copenhagen, dated Trondheim, 22 July 1769; as published by Behrend 1911 (quotes on p. 61). It might be added that his correspondence with Martfeld - of which merely two letters appear to survive - is permeated by frivolous humour and intimacy, which has led Liv Bliksrud to conclude that Bredal was, most probably, a homosexual (2010, 253-255). I do not find that discussion to be of any relevance here, however.

${ }^{19}$ Bredal (1756, preface, no page): “... haaber jeg, at vort Danske Sprog endog paa Skue-Pladsen igien skal erlange sin forlorne Borger-Rettighed."

${ }^{20}$ Ibid.: "Kierlighed til mit Moders Maal har været den eeneste Spore, der har drevet min Geist og ført min Pen."

${ }^{21}$ Classical scholar Johanna Akujärvi has in recent years studied paratexts (mainly prefaces) of early modern and modern Nordic translations of the classics (e.g. Akujärvi 2010). Although her research is most comprehensive regarding Sweden and Finland, we may assume that the widespread emphasis on "utility" found in Swedish translations from the eighteenth century was commonplace in Danish translations as well.

${ }^{22}$ Bredal 1758, preface, no page: “... det $\varnothing v$ vrige forhaaber jeg at den velmeenende Læser undskylder de Feyl, som en uhældig Oversætter kan have begaaet, ved at erindre sig ey alleene den almindelige Vanskelighed som forefalder ved Oversættelse fra Vers til Vers; men i Særdeleshed ved at forestille sig Originalens Geyst og det Latinske Sprogs Righed frem for alle andre Sprog." 